\title{
(6) \\ Opinion editorials: the science and art of combining evidence with opinion
} OPEN ACCESS

\section{$10.1136 /$ eb-2012-100996}

${ }^{1}$ Johnson-Shoyama Graduate School of Public Policy, University of Regina, Regina, Saskatchewan, Canada

${ }^{2}$ Collaboration for Innovation and Improvement, Canadian Foundation for Healthcare Improvement, Ottawa, Ontario, Canada

${ }^{3}$ Manitoba Centre for Health Policy, Department of Community Health Sciences, Faculty of Medicine, University of Manitoba, Winnipeg, Manitoba, Canada

Correspondence to: Gregory P Marchildon Johnson-Shoyama Graduate School of Public Policy, University of Regina, Regina, Saskatchewan, S4S 0A2, Canada greg.marchildon@uregina.ca

\section{Gregory P Marchildon, ${ }^{1}$ Jennifer $Y$ Verma, ${ }^{2}$ Noralou Roos $^{3}$}

\section{Abstract}

In the policy environment, the news media play a powerful and influential role, determining not only what issues are on the broad policy agenda, but also how the public and politicians perceive these issues. Ensuring that reporters and editors have access to information, that is, credible and evidence-based is critical for stimulating healthy public discourse and constructive political debates. EvidenceNetwork.ca is a non-partisan webbased project that makes the latest evidence on controversial health-policy issues available to the Canadian news media. This article introduces EvidenceNetwork.ca, the benefits it offers to journalists and researchers, and the important niche it occupies in working with the news media to build a more productive dialogue around healthcare.

\section{Introduction}

Through knowledge transfer and exchange (KTE), health research can inform healthcare professionals and managers-frequently with excellent results and to the benefit of patients and the public. Many health researchers believe knowledge is a societal good and assume that their research is accessible to those who need it. One study of the newspaper coverage of two prominent medical journals, the New England Journal of Medicine and The Journal of the American Medical Association, demonstrated the extent to which the articles addressing issues of public interest were given prominence and extensive coverage in a timely manner. ${ }^{1}$ However, communicating health research outside an academic audience is rarely straightforward, as health issues can be highly charged, attracting news media coverage and public debates. All too often, everyone from advocates and governments to scientists and experts struggle with an issue-its facts and fictions-through the news media glare.

Most health researchers shun media-based KTE because their expertise is limited and they fear misinterpretation (see table 1). These reasons appear to be corroborated in studies examining the barriers journalists face in reporting on health. ${ }^{2-6}$ One study involving medical journalists from 37 countries found reporters have difficulty translating scientific terminologies, understanding the impact of study findings and finding reliable sources willing to speak on record. ${ }^{3}$ Several sources have described a long-standing complaint of researchers-that journalists sometimes overstate or sensationalise study findings, introducing inaccuracies and misleading the public about the implications of research findings. ${ }^{7-9}$

\section{Introducing EvidenceNetwork.ca}

EvidenceNetwork.ca was established as a non-partisan, web-based facilitator to make evidence-based health research on Canadian health policy available to the media. ${ }^{10}$ It connects journalists with health services and policy experts to provide access to credible, evidencebased information. It offers expertise in eight areas: (1) ageing population and its impact on healthcare, (2) healthcare costs and expenditure, (3) appropriateness (retitled 'more care is not always better'), (4) the determinants of health ('health is more than health care'), (5) patient financing of healthcare ('the patient pays'), (6) private-for-profit solutions to funding and delivery, (7) sustainability and (8) waiting for care. These topics were selected on the basis that they are among the highest prioritised health services and policy themes in Canada. ${ }^{11}{ }^{12}$ They all have a vast research basis, but are often misrepresented in the news, reflecting conflict among differing ideologies or deeply ingrained but unsubstantiated assumptions about the subject matter. $^{13} 14$

\section{Preparing academics to write op-eds}

For researchers who have never written an opinion editorial (or op-ed for 'opposite the editorial page') for a newspaper, EvidenceNetwork.ca provides guidance and examples. It offers access to a professional editor to refine op-ed drafts, editing to make the piece copy-ready and provides strategic advice on potential angles.

Through the editor and a contract with a news service, the op-eds are disseminated to the highestcirculation newspapers and then to dozens of local community, niche, ethnic and online media across the country. This results in op-eds being reprinted multiple times. Research experts agree to respond to news media

Table 1 Reasons why health researchers avoid the news media and proposed solutions for addressing their concerns

\begin{tabular}{ll}
\hline Reasons/concerns & Mitigation strategies \\
\hline $\begin{array}{l}\text { Apprehensive to speak } \\
\text { beyond one's field of }\end{array}$ & $\begin{array}{l}\text { Be willing to reach modestly } \\
\text { expertise }\end{array}$ \\
of expertise & Facilitate an understanding \\
of the subject matter by \\
connecting the dots \\
between one's professional \\
work and the policy world \\
Stay anchored within one's \\
expertise \\
or taken out of context & Write an opinion editorial, \\
& columns that are prepared \\
& and signed by individuals \\
& appearing on the page \\
& opposite the standard \\
& newspaper editorial pages \\
& Writer is able to keep a \\
& greater control over how \\
evidence is presented to the & public \\
\hline
\end{tabular}


enquiries within $2 \mathrm{~h}$ and to report their media contacts to EvidenceNetwork.ca.

Recently, two members of EvidenceNetwork.ca prepared and facilitated a workshop for researchers at the Canadian Association for Health Services and Policy Research annual conference. ${ }^{15}$ Although both were health researchers, they spent part of their professional lives dealing with the media, one through senior positions in government and Royal Commissions and the other as a journalist and professional communicator. They were joined by a journalist-professor and a KTE expert. The workshop introduced the art and science of op-ed writing to approximately 50 health researchers including biomedical and clinical health services and population-health researchers. Participants self-selected into four theme groups: (1) activity-based funding (aligned with the EvidenceNetwork.ca themes: private-for-profit solutions to funding and delivery, and healthcare costs and spending), (2) mammography screening (waiting for care), (3) an ageing population and the fiscal sustainability of the healthcare system and (4) generic versus brand-named drugs (healthcare costs and spending). These themes were selected because they are timely, evidence-based and topics for which EvidenceNetwork.ca has already produced op-eds. As a background, we provided participants with a recent news article and research summary. We then asked each of the groups to address the following questions:

- What central focus will your op-ed take?

- Is it topical? Does it offer a new angle? How might you open and close the op-ed?

- What are your key lines of argument? What are your key facts?

- What other research, evidence or sources would you like to consider?

- What is the greatest struggle you face in preparing and publishing this op-ed?

After a report back from each team, participants received an EvidenceNetwork.ca op-ed on their theme. We learned three main lessons from the workshop about health researchers:

1 They encounter difficulty in focusing on a single dimension, because they tend to see many problems and complications within a research domain. They need to learn the art of isolating a single problem that they can address for each op-ed.

2 They often rely on the scientific debate rather than the public debate as their criteria for choosing their primary focus, and they need to learn how best to fit their concern into the current state of public discourse rather than the other way around.

3 They are apprehensive about entering public debates that extend beyond their obvious expertise. Here, they need to consider their role as citizens, not simply experts, and give themselves the right to have an opinion on issues that extend beyond their narrow body of expertise, and learn how to connect the dots between their professional work and the policy world around them.

All of these issues are addressed, in one form or another, by EvidenceNetwork.ca. Although only established in April 2011, it is possible to conduct a preliminary analysis of the impact of this new organisation.

\section{Evaluating EvidenceNetwork.ca}

The evaluation plan for the network was developed after examination of the efforts of similar agencies worldwide. ${ }^{16-20}$ For example, the Science Media Centre in the UK uses the following indicators to evaluate its efforts.

- Media briefings-how many briefings resulted in how many articles, and how many briefings achieved across-the-board coverage in press, radio and television

- Press releases-number per year

- Media inquiries-number and what prompted the inquiry

- Interviews-how many times reporters called and set up interviews ${ }^{16}$

The Australia Science Media Centre and the Science Media Centre of Canada use similar indicators. ${ }^{17}{ }^{18}$ EvidenceNetwork.ca assesses its effectiveness in four ways: (1) track the number of op-eds published and assess the size of the public reached, (2) monitor website use overtime, (3) get feedback from the media and (4) critically review news published before and after its interventions.

Publishing op-eds is important because it enables experts to communicate evidence directly to the public. EvidenceNetwork.ca's success in reaching its audience is presented in figure 1 . The total number of op-eds published is determined by the number of op-eds written by health researchers multiplied by the number of newspapers that publish each op-ed. The high numbers written in May 2011 represent the kick-start of the network's op-ed strategy, whereas the numbers in February 2012 reflect the invitation from The Hill Times (an independent weekly newspaper on Canadian federal politics) to contribute to an issue on health policy. These numbers do not include reprints in French news publications. The population reached is also influenced by the size of the publication and, in recent months, Canada's larger newspapers have published more EvidenceNetwork.ca op-eds. The network is recruiting more experts too, to scale-up its op-ed production. The network is also monitoring its website usage (using Google Analytics) and interviewing journalists. Data are being collected to assess the quality of news coverage before, during and after op-ed interventions.

\section{Conclusion}

The news media play a powerful and influential role determining what issues are on the public and political agendas and how the public and politicians perceive these issues. Ensuring that reporters and editors have access to credible, evidence-based information is critical for stimulating a healthy public dialogue. EvidenceNetwork.ca provides access to such information in the health-policy domain. Although still in its infancy, the network is becoming an invaluable resource that makes sense of controversial health policy issues, primarily through easing access for journalists to experts and pushing the experts' interpretation of the evidence out to the public via op-eds. 


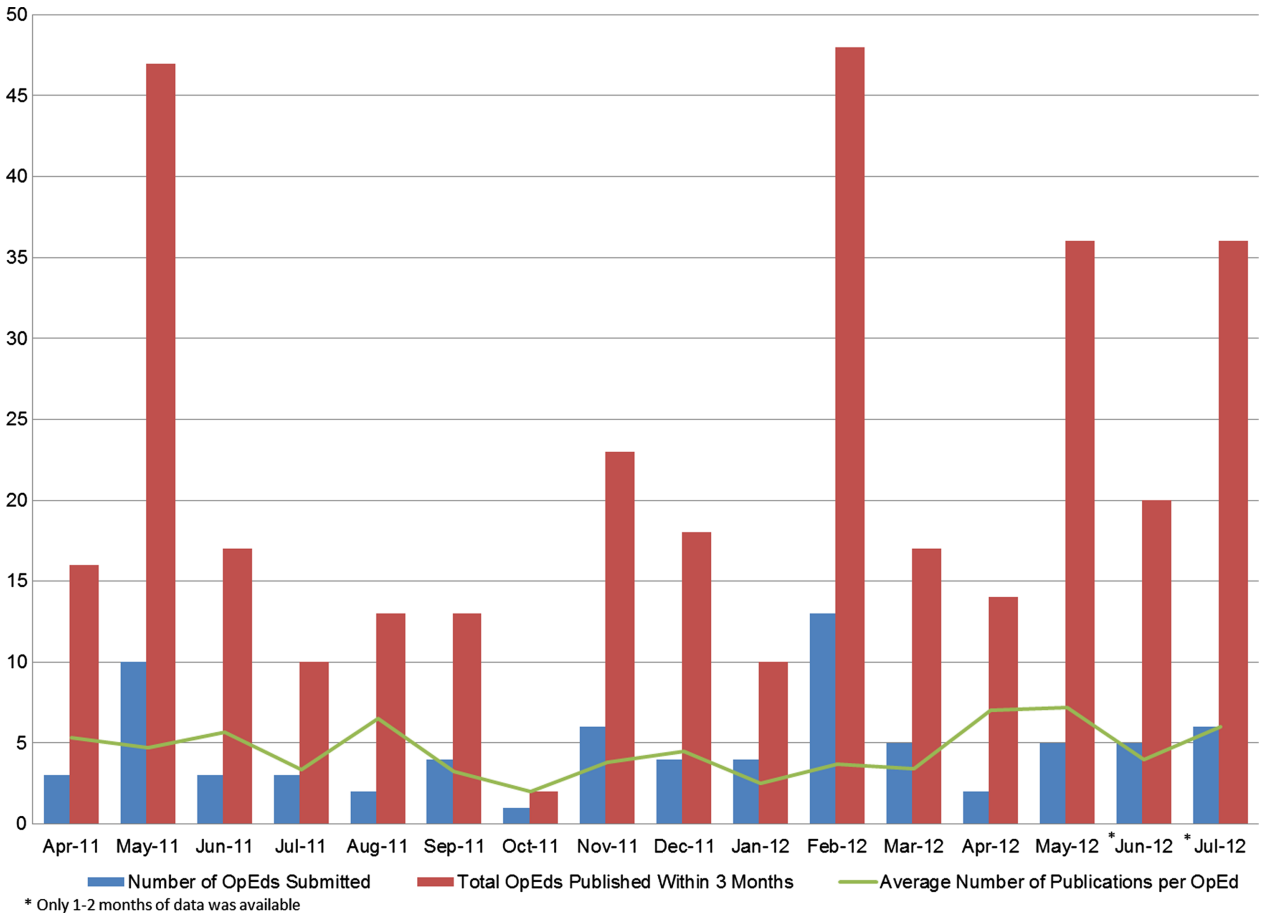

Figure 1 Total number of op-eds published in the first 16 months by EvidenceNetwork.ca. This figure is only reproduced in colour in the online version.

Acknowledgements The authors acknowledge the contributions of Kathleen 0'Grady, Sharon Manson Singer and Gary Slywchuk. Kathleen 0'Grady is the network's Director of Communications and a Research Associate with Simone de Beauvoir Institute at Concordia University, and Director, QUOI Media Group. Sharon Manson Singer is the Co-Founder of EvidenceNetwork. ca and a Professor of Public Policy at Simon Fraser University. Gary Slywchuk is the CEO of Troy Media, the media service used by the network. Special thanks to Lindsay Wilson, an intern with the Canadian Foundation for Healthcare Improvement, who provided assistance with referencing as well as Shannon Turczak, the administrative assistant for EvidenceNetwork.ca, who created the figure.

Funding EvidenceNetwork.ca has been established with the help of a grant funding from the Canadian Institutes of Health Research (Grant \#: 200904PHE-205389) and the Manitoba Health Research Council, as well as extensive consultation with experienced news media advisors, researchers across the country and the third-party evidence brokers including the Canadian Foundation for Healthcare Improvement (formerly the Canadian Health Services Research Foundation), the Canadian Institute for Health Information and the Health Council of Canada.

Competing interests None.

Open Access This is an Open Access article distributed in accordance with the Creative Commons Attribution Non Commercial (CC BY-NC 3.0) license, which permits others to distribute, remix, adapt, build upon this work non-commercially, and license their derivative works on different terms, provided the original work is properly cited and the use is non-commercial. See: http:// creativecommons.org/licenses/by-nc/3.0/

\section{References}

1. Burns RB, Moskowitz MA, Osband MA, et al. Newspaper reporting of the medical literature. J Gen Intern Med 1995;10:19-24.

2. Johnson T. Medicine and the media. $N$ Engl J Med 1998;339:87-92

3. Larsson $\mathrm{A}$, Oxman $\mathrm{AD}$, Carling $\mathrm{C}$, et al. Medical messages in the media-barriers and solutions to improving medical journalism. Health Expect 2003;6:323-31.

4. Schwartz LM, Woloshin S. The media matter: a call for straightforward medical reporting. Ann Intern Med 2004;140:226-8.

5. Wilson K, Code C, Dornan C, et al. The reporting of theoretical health risks by the media: Canadian newspaper reporting of potential blood transmission of Creutzfeldt-Jakob disease. BMC Public Health 2004;4:1-9.

6. Winsten JA. Science and the media: the boundaries of truth. Health Aff 1985;4:5-23.

7. Nelkin D. An uneasy relationship: the tensions between medicine and the media. Lancet 1996;347:1600-3.

8. Shuchman M, Wilkes MS. Medical scientists and health news reporting: a case of miscommunication. Ann Intern Med 1997;126:976-82.

9. Seale C. Health and media: an overview. Social Health Illn 2003;25:513-31.

10. Evidence Network. Welcome to the Health Evidence Network of Canada. Evidencenetwork.ca (accessed Jul 2012).

11. Canadian Foundation for Healthcare Improvement (formerly, the Canadian Health Services Research Foundation). Listening for Direction III: National Consultation on Health Services and Policy Issues 2007-2010. 2008. http://www.chsrf.ca/Libraries/ 
Listening_for_Direction/LfDIII-FINAL_ENG.sflb.ashx (accessed Jul 2012).

12. Canadian Institutes of Health Research. Evidence-Informed Healthcare Renewal. 2012. http://www.cihr-irsc.gc.ca/e/43628. html (accessed Jul 2012).

13. Thornhill J, Clements D, Neeson J. Myths, 'zombies' and “'Damned Lies”' Plague Canadian Healthcare Systems: What's a Researcher to do? Healthc Q 2008;11:14-15.

14. Mythbusters-using evidence to debunk common misconceptions in Canadian healthcare. 2012. http://www.chsrf.ca/publicationsandresources/mythbusters.aspx (accessed Jul 2012).
15. Canadian Association for Health Services and Policy Research. 2012. http://www.cahspr.ca/ (accessed Jul 2012).

16. UK Science Media Centre. 2012. http://www. sciencemediacentre.org/pages/ (accessed Jul 2012).

17. Australian Science Media Centre. 2012. http://www.smc.org.au/ (accessed Jul 2012).

18. Science Media Centre of Canada. 2012. http://www. sciencemediacentre.ca/smc/ (accessed Jul 2012).

19. Media Doctor Australia. The Newcastle Institute of Public Health. http://www.mediadoctor.org.au/ (accessed Jul 2012).

20. Media Doctor Canada. http://www.mediadoctor.ca/ (accessed Jul 2012). 